University of Arkansas, Fayetteville

ScholarWorks@UARK

$2-1-2016$

\title{
The Impact of the Louisiana Scholarship Program on Racial Segregation in Louisiana Schools
}

Anna J. Egalite

North Carolina State University

Jonathan N. Mills

Education Research Alliance for New Orleans

Patrick J. Wolf

University of Arkansas, Fayetteville, pwolf@uark.edu

Follow this and additional works at: https://scholarworks.uark.edu/scdp

Part of the Education Policy Commons, Public Policy Commons, and the Social Policy Commons

\section{Citation}

Egalite, A. J., Mills, J. N., \& Wolf, P. J. (2016). The Impact of the Louisiana Scholarship Program on Racial Segregation in Louisiana Schools. School Choice Demonstration Project. Retrieved from https://scholarworks.uark.edu/scdp/18

This Report is brought to you for free and open access by the Education Reform at ScholarWorks@UARK. It has been accepted for inclusion in School Choice Demonstration Project by an authorized administrator of ScholarWorks@UARK. For more information, please contact scholar@uark.edu. 
Technical Report

\section{THE IMPACT OF THE LOUISIANA SCHOLARSHIP PROGRAM ON RACIAL SEGREGATION IN LOUISIANA SCHOOLS}

\section{EDUCATION RESEARCH ALLIANCE}

FOR NEW ORLEANS

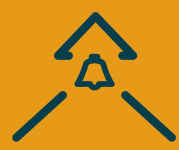

SCHOOL CHOICE DEMONSTRATION

PROJECT

Anna J. Egalite, Jonathan N. Mills, \& Patrick J. Wolf

February 22, 2016

Education Research Alliance NOLA.com

UAedreform.org/school-choice-demonstration-project 


\title{
THE IMPACT OF THE LOUISIANA SCHOLARSHIP PROGRAM ON RACIAL SEGREGATION IN LOUISIANA SCHOOLS
}

\author{
Anna J. Egalite \\ (Corresponding author) \\ Department of Educational Leadership, Policy, and Human Development \\ North Carolina State University \\ Raleigh, NC, 27695 \\ Anna_Egalite@ncsu.edu \\ Jonathan N. Mills \\ The Education Research Alliance for New Orleans \\ New Orleans, LA 70112 \\ jmills10@tulane.edu \\ Patrick J. Wolf \\ Department of Education Reform, \\ University of Arkansas \\ Fayetteville, AR 72701 \\ pwolf@uark.edu
}

Louisiana Scholarship Program Evaluation Report \#3

March $2016^{1}$

School Choice Demonstration Project, University of Arkansas, Fayetteville, AR Education Research Alliance, Tulane University, New Orleans, LA

A version of this study is forthcoming in Education and Urban Society

\section{Acknowledgments}

We thank the Smith Richardson Foundation for financial support for this research. The content of the report is solely the responsibility of the authors and does not necessarily represent the views of the Smith Richardson Foundation, North Carolina State University, University of Arkansas, or Tulane University. We gratefully acknowledge Jay P. Greene and Robert M. Costrell for their extensive helpful comments on previous drafts and the Louisiana Department of Education for their cooperation and assistance with providing the necessary data to conduct the analyses.

\footnotetext{
${ }^{1}$ March draft includes appendix tables.
} 


\title{
The Impact of the Louisiana Scholarship Program on Racial Segregation in Louisiana Schools
}

\begin{abstract}
The question of how school choice programs affect the racial stratification of schools is highly salient in the field of education policy. We use a student-level panel data set to analyze the impacts of the Louisiana Scholarship Program (LSP) on racial segregation in public and private schools. This targeted school voucher program provides funding for low-income, mostly minority students in the lowest-graded public schools to enroll in participating private schools. Our analysis indicates that the vast majority (82\%) of LSP transfers have reduced racial segregation in the voucher students' former public schools. LSP transfers have marginally increased segregation in the participating private schools, however, where just $45 \%$ of transfers reduce racial segregation. In those school districts under federal desegregation orders, voucher transfers result in a large reduction in traditional public schools' racial segregation levels and have no discernible impact on private schools. The results of this analysis provide reliable empirical evidence that parental choice actually has aided desegregation efforts in Louisiana.
\end{abstract}

Keywords: racial segregation; school vouchers; school choice; systemic effects; integration 


\section{The Impact of the Louisiana Scholarship Program on Racial Segregation in Louisiana Schools}

\section{Introduction}

Many contemporary education reform policies attempt to apply market principles to K-12 education, under the assumption that choice and competition will spur improvements across the entire education system. One such system-wide or "systemic" effect is the crucial issue of racial segregation in schools, defined here as the voluntary separation of people into distinctive racial or ethnic groups. As private school voucher and tuition tax credit scholarship programs continue to expand across the United States, will their proliferation undermine an important civic goal, namely improved racial and ethnic integration?

The Louisiana Scholarship Program (LSP) is a statewide school choice program that enables low-income students in under-performing public schools to enroll in participating private schools at the state's expense. Although a pilot version of the program has operated in the city of New Orleans since 2008, Act 2 of the 2012 Regular Session expanded the program statewide. As a result, almost 10,000 eligible Louisiana students applied for LSP vouchers in school year 201213, which were allocated by lottery by the state department of education. Approximately 5,000 public school students ultimately used a voucher to enroll in one of 117 private schools across the state, the majority of which were Catholic schools. By program design, all of these students were low-income and had previously attended a low-performing public school, with the exception of kindergarten applicants, who were only subject to the family income requirement. ${ }^{2}$

\footnotetext{
${ }^{2}$ Twenty one percent of applicants to the 2012-13 cohort applied for scholarships to attend Kindergarten.
} 
This article examines how voluntary school transfers made possible by LSP vouchers impacted racial segregation in public and private schools in Louisiana in the first year of the program's statewide operation. Many commentators have claimed that school choice programs worsen segregation along racial and ethnic lines by giving students the resources to exit a residentially-assigned public school in favor of a private school of choice (Cobb \& Glass 1999; Berliner, Farrell, Huerta, \& Mickelson 2000; Frankenberg, Siegel-Hawley, \& Wang 2010). Such concerns are particularly relevant in Louisiana, a state that relied on Jim Crow laws to justify the operation of "dual racially segregated systems of pupil assignment" until the 1969-70 school year (Brumfield v. Dodd, 1975).

Although the landmark Brown v. Board of Education of Topeka, Kansas (1954) decision marked the beginning of court supervision of school desegregation efforts, implementation lagged several years behind the Brown decision. Louisiana schools did not begin to integrate until 1960, when the city established a plan for the desegregation of two New Orleans elementary schools in the lower Ninth Ward. On November 14, 1960, Leona Tate, Tessie Prevost, and Gaile Etienne entered McDonogh No. 19 Elementary and six-year-old Ruby Bridges entered William J. Frantz Elementary, each escorted by United States marshals for protection (Landphair, 1999). In response to these early desegregation efforts, white parents began to withdraw their children from Louisiana's public schools and enroll them in segregated private academies.

Given the slow pace of integration, a series of decisions by the United States Supreme Court in 1969 and 1970 ordered Louisiana school boards to eliminate or integrate all-black schools. Today, the federal government continues to oversee public schools in 34 Louisiana school districts to ensure they are observing active desegregation plans. Brumfield v. Dodd 
(1975) marked the end of state financial assistance of any kind in Louisiana for private schools with admissions policies that segregate or discriminate. ${ }^{3}$ This includes funding for textbooks, school supplies, student transportation, or classroom materials. In August 2013, the U.S. Justice Department filed a motion in the Brumfield lawsuit, seeking an injunction against the LSP, alleging that the program increases racial segregation. After several months of negotiations between the State of Louisiana and the Justice Department, the U.S. District Court issued a decree that the state must provide the federal government with information on LSP applicants, including student race, at least 10 days before scholarships are awarded. In November 2015, however, the Fifth Circuit Court of Appeals overturned the District Court's decree in a 2-1 decision, noting the reporting requirement was "beyond the scope of district court's continuing jurisdiction in this case"(Brumfield v. Louisiana State Board of Education, 2015).

Given the ongoing efforts to reduce segregation in Louisiana's public schools as well as the legal attention surrounding this issue, it is important to determine how the LSP affects racial segregation. Critics of school vouchers allege that school vouchers will increase segregation in schools as poor white families flee integrated public schools for segregated private schools. This claim has a historical precedent in the segregation academies developed in the South during the 1970s (Ladson-Billings, 2004). In this study, we empirically examine the issue using data on LSP voucher users. By tracking individual students across time as they move from the public to private sector, we can quantitatively determine if these transfers increased or reduced racial segregation at students' former public schools (sending schools) and current private schools (receiving schools) by nudging the school's racial composition nearer to or further from the racial composition of the surrounding community.

\footnotetext{
${ }^{3}$ Brumfield v. Dodd focused on the actions of a local public school board in Louisiana that donated desks and a library to a private school (Ladson-Billings, 2004).
} 
In general our analysis indicates that access to additional educational choices for lowincome students has decreased racial segregation in public schools in Louisiana, a welcomed outcome for a state with a history of state-sponsored segregation. Findings for private schools, however, suggest that just $45 \%$ of transfers reduce racial segregation in those "receiving" schools. Since the positive effect of student transfers on better integrating the public schools they left is much larger than the negative effect of student transfers on reducing integration in the private schools that receive them, the net effect of the LSP on school-level racial integration across both school sectors is positive.

The results of this analysis provide empirical evidence that can be used to inform ongoing debates both inside and outside of the courtroom over whether or not parental choice is harming current desegregation efforts in Louisiana's schools. It also provides an example of how the effects of school choice interventions on segregation should be evaluated based on careful consideration of the counterfactual - the segregation level that exists under the status quo.

The remainder of this article proceeds as follows. First, we provide a summary of the literature examining the impacts of school choice programs on racial segregation. In the next section, we describe the data used in our analysis and our empirical methodology. The following section presents the results. Finally, we conclude with a summary of the findings and a discussion of their implications for public policy.

\section{Previous Literature}

\section{School choice and the achievement gap}

The merits of a particular school choice proposal must be considered first from a philosophical perspective. Most scholars agree that the state is obligated to find a balance between the private needs of parents, children, and educators and the public good (Glenn, 2011; Macedo \& Wolf 
2004), particularly as it relates to closing racial achievement gaps (Jeynes, 2014a). What constitutes an acceptable tipping point varies by context, however. Glenn (2011) observes that countries such as Germany and Austria view the provision of education as a responsibility of the state, whereas the Netherlands and Belgium entrust education to institutions of civil society. In the United States, there is no consensus on which conception of the provision of education is most appropriate (Galston, 2004).

The theoretical arguments for and against choice take into consideration both the participant and systemic effects of such proposals. On the one hand, proponents of school choice argue that private institutions are best situated to offer diverse, high-quality educational experiences (Friedman, 1955). Scholars argue that the competition resulting from a market approach to education will spur overall improvements (Greene, 2011) and will particularly benefit student subgroups that are currently underserved, such as low-income and minority students in urban areas (Peterson, 2006). Because the achievement gap between majority and minority students is much smaller in private schools than in public schools, some scholars have posited than an expanded system of school choice would result in a narrowing of the national achievement gap (Jeynes, 2014b). On the other hand, opponents of school choice argue that the siphoning of state funds to private, often religious, institutions represents an abdication of the state's responsibility to provide a stable, equitable, and communal system of public education (Henig, 1994) and that it undermines the integrationist goal of preparation for democratic citizenship (Gutmann, 2002). Opponents also claim that selective private schools will refuse admission to the hardest-toeducate students, resulting in inequitable educational opportunities (Altonji, Huang, \& Taber, 
2015) particularly for subgroups of high-needs students such as those with English language deficiencies or special educational needs (Lacireno-Paquet, Holyoke, Moser, \& Henig, 2002). ${ }^{4}$

As school choice options proliferate across the states (Frendeway et al., 2015), much remains unknown about the impacts associated with transitioning from a traditional public school system to state-sponsorship of privately run and largely autonomous private schools of choice (Jeynes, 2000). This study's contribution to that literature is an examination of the localized impacts of a statewide private school choice program on racial segregation.

\section{The effect of school choice on racial segregation}

Previous studies on this topic used either cross-sectional data or panel data examining actual student transfers. These two types can be further subdivided by method of analysis, resulting in a set of four general methods used to understand the impact of school choice programs on racial segregation. To assist the reader, Figure 1 presents a typology of all the racial segregation measures identified in our literature review.

Studies in the top left quadrant of Figure 1 rely on descriptive comparisons of users and eligible non-users. Henig (1996) notes that minorities were less likely to participate in a magnet school program in Maryland and that white transfer requests were for schools with high proportions of other white students in the student body. Willms and Echols (1993) use a similar approach to study a school choice program in Scotland, finding that parents whose children had exercised the school choice option were more likely to have a prestigious occupation and to have attained a higher level of education. Nevertheless, while this approach helps describe the types of

\footnotetext{
${ }^{4}$ This is not a concern for the LSP, which strongly prioritizes students with disabilities in the scholarship award algorithm.
} 


\begin{tabular}{|c|c|c|c|}
\hline \multirow{2}{*}{\multicolumn{2}{|c|}{$\begin{array}{c}\text { Typology of Racial } \\
\text { Segregation } \\
\text { Measures }\end{array}$}} & \multicolumn{2}{|c|}{ Uses a Racial Composition Benchmark } \\
\hline & & NO & YES \\
\hline \multirow[t]{2}{*}{$\begin{array}{c}\text { Data } \\
\text { Structure }\end{array}$} & $\begin{array}{c}\text { Cross- } \\
\text { Sectional }\end{array}$ & $\begin{array}{l}\text { Descriptive Comparisons } \\
\text { of Users v. Eligible Non- } \\
\text { Users } \\
\text { (Henig, 1996; Willms \& } \\
\text { Echols, 1993) }\end{array}$ & $\begin{array}{l}\text { Within-District Sector Comparisons of } \\
\text { School Racial Composition } \\
\text { (Burgess, Wilson, \& Lupton, 2005; } \\
\text { Clotfelter, 1999; Frankenberg \& Lee, 2002; } \\
\text { Frankenberg, Siegel-Hawley, \& Wang, } \\
\text { 2010; Fuller \& Greiveldinger, 2002; Fuller } \\
\text { \& Mitchell, 1999, 2000; Garcia, 2008) } \\
\text { Within-CBSA Sector Comparisons of } \\
\text { School Racial Composition } \\
\text { (Bifulco \& Ladd, 2006; Forster, 2006a, } \\
\text { 2006b; Greene, 1998; Greene, Mills, \& } \\
\text { Buck, 2010; Greene \& Winters, 2007; } \\
\text { Ritter, Rush \& Rush, 2002) }\end{array}$ \\
\hline & Panel & $\begin{array}{l}\text { Transfer Measures with } \\
\text { No Benchmark } \\
\text { (Zimmer et al., 2009) }\end{array}$ & $\begin{array}{l}\text { Transfer Measures with a District } \\
\text { Benchmark } \\
\text { (Bifulco \& Ladd, 2006) } \\
\text { Transfer Measures with a CBSA } \\
\text { Benchmark (Greene, Mills, \& Buck, } \\
\text { 2010; Ritter, Jensen, Kisida, \& Bowen, } \\
\text { 2014) }\end{array}$ \\
\hline
\end{tabular}

Figure 1. Typology of Racial Segregation Measures. 
students who actually access a given program, it does not capture impacts on racial segregation because it fails to examine school-level segregation before and after the program takes effect.

Studies in the top right quadrant of figure 1 also take a cross-sectional approach. These studies use a racial composition benchmark such as the district or core-based statistical area (CBSA) to judge the relative level of racial segregation for schools in each sector and then compare the snapshots across the public and private sectors. Measures like the dissimilarity index (Clotfelter 1999; Burgess, Wilson, \& Lupton 2005) and exposure index (Frankenberg \& Lee 2002; Garcia 2008) take this approach, using the district as the benchmark. These measures are weak, however, because their focus on strictly within-district comparisons fails to account for existing segregation across school districts in the same area (Greene 2005), which often is high (Clotfelter 1999). For example, a within-district measure like these would classify a public school that is $100 \%$ white in a school district that is $100 \%$ white as being perfectly integrated, even if it is adjacent to a district that is $100 \%$ black. Moreover, a within-district measure would be particularly inappropriate to use in Louisiana, where the LSP actively allows students to enroll in schools across district boundaries. ${ }^{5}$

Within-CBSA studies, on the other hand, use the demographic characteristics of the surrounding metropolitan or micropolitan area instead of the district as a benchmark of the desired racial composition for a school. Forster uses this approach to compare public and private schools in Cleveland (2006a) and Milwaukee (2006b), finding that private schools participating in the Cleveland and Milwaukee voucher programs were less segregated, on average, than neighboring public schools. Greene, Mills, and Buck (2010) also use this approach in their study

\footnotetext{
5 Twenty-four percent of voucher users actually crossed their district boundary to attend a private school in a neighboring district through the program in its first year.
} 
of segregation in Milwaukee, WI. They find that, in some years, the voucher program schools better approximate the metro area in racial demographics and in other years the public schools better approximate this value but, over a three-year period from 2006-07 through 2008-09, neither sector comes close to approximating the percentage of white students in the metro area. Greene and Winters (2007) also employ this approach in their analysis of the effects of the Washington D.C voucher program, finding that neither the public nor private education sector is particularly well integrated in the nation's capital.

Studies in the bottom row of figure 1 take advantage of panel datasets to capture dynamic information on individual student transfers to estimate the overall impact of school choice programs on racial segregation, a major methodological advantage over the static cross-sectional studies in row 1 of figure 1.

The bottom left quadrant consists of transfer measures with no benchmark; only one study has taken this approach. Zimmer, Gill, Booker, Lavertu, Sass, and Witte (2009) measure charter school segregation across seven locations. They calculate the difference in the proportion of students of each race in the charter school a student switches into and the prior traditional public school the student attended. In the majority of cases, they show that students tend to transfer into schools that do not differ significantly in terms of racial makeup from the schools they left.

Studies in the bottom right quadrant feature transfer measures that use a racial composition benchmark. These studies take advantage of panel data to track individual students' migration patterns as they transfer between schools, judging whether these transfers help or hinder integration by whether they move a school towards or away from the racial diversity of the chosen benchmark. These studies typically use either the school district or CBSA as benchmarks; and have generally found encouraging results for school choice. Our study of the 
impact of the LSP on racial segregation in Louisiana's public and private schools belongs in this category.

Bifulco and Ladd (2006) use this approach to analyze changes in the racial isolation experienced by third through eighth grade students who transfer to charter schools in North Carolina between 1996-97 and 2001-02. Schools in which the proportion of black students is greater than 20 percentage points away from the district average are classified as "racially unbalanced." The authors then compare the proportion of students in each sector who attend a racially unbalanced school, finding that charter school students are approximately two and a half times more likely to attend one of these schools.

A small number of panel studies use the surrounding metropolitan or micropolitan area as the benchmark for the broader community (Greene, Mills and Buck 2010; Ritter, Jensen, Kisida, and Bowen 2014). These CBSAs are characterized by high degrees of social and economic interdependence and therefore represent a more appropriate benchmark of racial composition against which to judge progress than the district because they proxy for the geographical area from which a school could reasonably be expected to draw students in the absence of legal or political boundaries. Greene, Mills, and Buck (2010) track student transfer effects on both sending and receiving schools in Milwaukee, WI. They show that in 2007-08, 92\% of departing students tended to be a member of a racial/ethnic group that was overrepresented at their sending school, relative to the metro area. The departure of these students positively impacted racial integration efforts. The comparable statistic for $2008-09$ is $95 \%$. On the other hand, when they analyze the impact of student transfers on receiving schools, the reverse is true. In $2007-08,91 \%$ of student transfers reduced integration in the receiving schools. The comparable statistic for 2008-09 is $94 \%$. 
Finally, Ritter et al. (2014) use this approach to analyze the effects of charter school transfers in Little Rock, AR between 2004-05 and 2009-10. They show that white student transfers in this time period improved racial integration in the sending schools twice as often as they reduced it (25\% compared to $12 \%$ ). For minority students, student transfers improved racial integration in the schools they left more than three times as often as reducing it ( $48 \%$ compared to $15 \%)$. Impacts on receiving schools are not computed.

As this review of the literature reveals, a panel study of student migratory patterns brought about by the introduction of a school voucher program has never been conducted across an entire state. Given the increasing prevalence of large-scale school voucher programs like the LSP, this article provides a timely analysis of a potentially serious unintended consequence of more expansive school choice programs. Moreover, the data and methods that we use in the analysis have the important advantages of permitting us to examine the impact of the movement of actual students in a school choice program, over time, compared to an appropriate racial integration benchmark.

\section{Data}

This study relies upon data from five total sources. First, student-level data provided by the Louisiana Department of Education on LSP voucher users allow us to identify individual-level school transfers. Second, school-level data on the racial composition of Louisiana's private schools come from the Private School Universe Survey (PSS), a national survey of private elementary and secondary schools conducted by the National Center for Education Statistics (NCES) every two years since 1989-90. In particular, our analysis relies on school-level data collected in the 2011-12 school year; the year before the voucher program expanded statewide. Third, we collect corresponding data on the racial compositions of Louisiana's public schools in 
the 2011-12 school year from the NCES's Public Elementary/Secondary School Universe Survey. In the case of any missing data in either of these sources, we supplement with data from earlier versions of these same surveys. Fourth, we use 5-year population estimates from the American Community Survey, administered by the U.S. Census Bureau, to generate communitywide benchmarks of the school-age racial composition of Louisiana's Core Based Statistical Areas (CBSAs) in 2011-12. The final data source is the lawsuit filed by the U.S. Justice Department in August 2013, which identifies those Louisiana public school districts that are under federal desegregation orders.

\section{Sample selection}

Figure 2 describes how we generate the sample for our primary analysis. Starting with a studentlevel data set that includes all 9,831 eligible applicants for the LSP in its first year of statewide operation, we first narrow the sample to include only the 5,777 voucher winners identified in our data. Because all voucher winners didn't necessarily use their voucher, the next screen reduces the sample to 4,941 students who were voucher users. The third screen only keeps those voucher users who were not participants in the New Orleans pilot program because those students often enroll in the same school as the previous year, and therefore they are not relevant for this analysis of actual school switchers. This screen reduces the sample to 3,338 students. The fourth screen excludes those students who were missing a prior school identification code. This includes students entering Kindergarten or students moving to Louisiana from out of state. This brings the sample to 2,179 students. Fifth, those students who reside in rural areas that do not fall in a metropolitan or micropolitan area have to be excluded from our sample because we are unable to calculate the racial composition of the surrounding CBSA to use as the integration benchmark for them. This brings the sample to 2,117. Finally, because our analysis, and the legal 
and policy debate surrounding the issue, is focused on the integration impacts on traditional public schools, we exclude those students who previously attended a public charter school. Once this set of screening rules is employed, our final analysis sample consists of 1,741 students. ${ }^{6}$

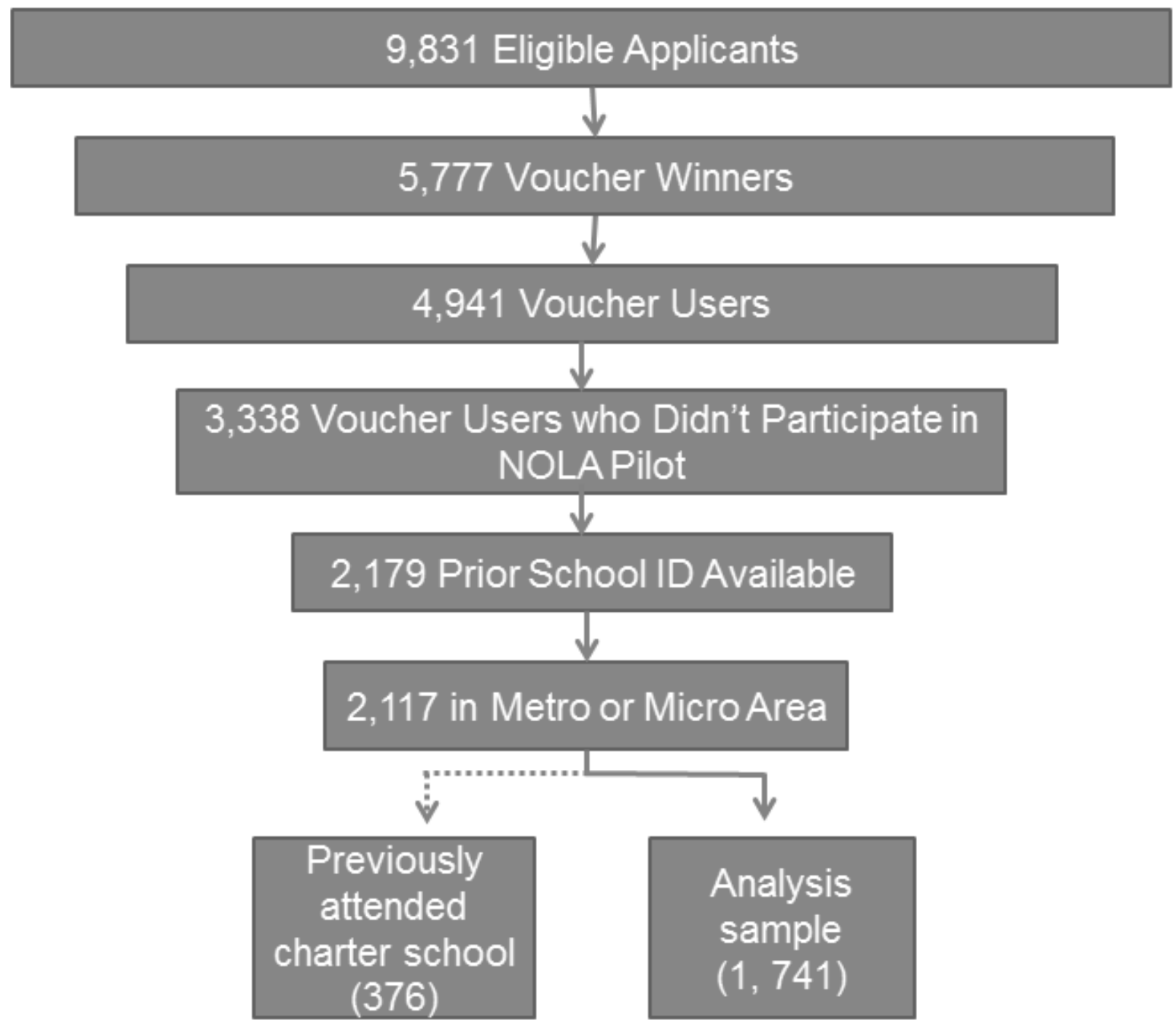

Figure 2. Creation of Student Sample for Primary Analysis of LSP Transfers

\section{Descriptive statistics for students}

While the primary analysis examines the effects of all LSP transfers that qualify for our sample, we also identify a subsample of students who are in a traditional public school district that is

\footnotetext{
${ }^{6}$ Our results are not sensitive to the additional exclusion of students attending other public schools of choice such as magnet and Orleans Parish School Board (OPSB) open-enrollment schools. See Appendix Table A2.
} 
under an active federal desegregation order. ${ }^{7}$ Table 1 presents descriptive statistics for both the primary analysis sample and the desegregation district subsample. There is an approximately even male/female split in both samples. Black students represent an overwhelming majority of LSP voucher users across both samples. Finally, the majority of observations come from the elementary grades of 1 through 5.

Table 1.

Descriptive Statistics for Analysis Sample and Subsample of Students in Desegregation Districts

Analysis Sample Desegregation District

(1) Subsample

(2)

\begin{tabular}{lrrrr}
\hline & $\mathrm{N}$ & $\%$ & $\mathrm{~N}$ & $\%$ \\
\hline Count & 1,741 & $100 \%$ & 493 & $100 \%$ \\
Male & 839 & $48 \%$ & 238 & $48 \%$ \\
Race/Ethnicity & & & & \\
$\quad$ Black & 1,395 & $80 \%$ & 367 & $74 \%$ \\
$\quad$ Hispanic & 75 & $4 \%$ & 13 & $3 \%$ \\
$\quad$ White & 218 & $13 \%$ & 93 & $19 \%$ \\
Other & 53 & $3 \%$ & 20 & $4 \%$ \\
Grade & & & & \\
Grades 1-5 & 1,070 & $61 \%$ & 313 & $63 \%$ \\
Grades 6-8 & 436 & $25 \%$ & 119 & $24 \%$ \\
Grades 9-12 & 235 & $13 \%$ & 61 & $12 \%$ \\
\hline
\end{tabular}

Note: The desegregation district subsample is composed of public schools in the 34 public school districts that are currently under desegregation orders (see Table A1 in the appendix for a full list).

Source. Authors' calculations.

\section{Descriptive statistics for schools}

In order to provide context for this study, we also present descriptive statistics of public and private schools in Louisiana at baseline using two widely-used segregation measures. First, Table 2 examines the existing differences in school-level segregation across both public and private

\footnotetext{
${ }^{7}$ The details of individual desegregation orders vary by school district, but require a school district to submit a desegregation plan for the court's approval and commit to annual progress reports. Such plans might outline efforts to improve black participation in certain programs such as gifted study programs or AP and honors courses; efforts to ensure resource allocations are equitable across all schools in a district, and efforts to preserve the racial diversity of teachers in the schools.
} 
school environments using the "segregation index". The segregation index is traditionally calculated as the absolute value of the difference between each school's percentage of minority students and the percentage of minorities in the school-aged population of the broader community (in this case the CBSA). By taking the absolute value of this difference, the segregation index provides a picture of how far schools are from the CBSA's percentage minority, irrespective of directionality. Table 2 additionally presents results for a "raw" segregation index, which is simply the difference between a school's percentage minority and the CBSA. The raw segregation index offers more contextual information, allowing us to gauge if school environments are, on average, under- or over-representative of the percent minority in the broader community (represented by negative and positive values, respectively). Both measures are weighted by sector-specific student enrollment, providing an idea of the school environment facing the average student in each sector.

Panel A in Table 2 presents results for the traditional segregation index. When comparing public schools to private schools on this measure, we find that both sectors are segregated and that the private schools are slightly more segregated, on average, than the public schools. Private schools are 27.9 percentage points from the community average racial demographic, whereas public schools are 25.5 percentage points from the community average. We can also break out the data to compare private and public schools within CBSA classifications - metro and micro areas. While we observe no statistically significant differences between sectors in metropolitan areas, private schools are significantly more segregated than public schools in micropolitan areas, with a difference of about 6 percentage points between the two sectors.

The results presented in Panel B indicate that the average private school student in Louisiana is in an educational environment with fewer minority students than their broader 
community. In contrast, the percentage minority of schools attended by the average public school student is slightly higher than that of the broader community. Moreover, the differences between private and public schools are significant in all geographic locales.

Table 2.

Enrollment-Weighted Average Distance from the Percentage Minority of the CBSA, by sector

\begin{tabular}{lcccccc}
\hline & \multicolumn{2}{c}{ Private Schools } & \multicolumn{2}{c}{ Public Schools } & \multicolumn{2}{c}{ Comparison } \\
\cline { 2 - 7 } & $\mathrm{n}$ & $\begin{array}{c}\text { Distance } \\
\text { from CBSA }\end{array}$ & $\mathrm{n}$ & $\begin{array}{c}\text { Distance } \\
\text { from CBSA }\end{array}$ & Difference & $p$-value \\
\hline Panel A: Segregation Index & 332 & 27.92 & 1278 & 25.46 & $2.46^{* *}$ & 0.02 \\
TOTAL & 282 & 28.32 & 953 & 27.06 & 1.25 & 0.24 \\
Metro Areas & 50 & 25.40 & 325 & 19.75 & $5.65^{* *}$ & 0.01 \\
Micro Areas & 332 & -19.50 & 1278 & 5.90 & $-25.43^{* * *}$ & 0.00 \\
Panel B: "Raw" Segregation Index & 282 & -19.00 & 953 & 6.40 & $-25.36^{* * *}$ & 0.00 \\
TOTAL & 50 & -22.73 & 325 & 4.40 & $-27.11^{* * *}$ & 0.00 \\
Metro Areas & & & & & & \\
Micro Areas & & & & & & \\
\hline
\end{tabular}

*** $-\mathrm{p}<.01, * *-\mathrm{p}<.05, *-\mathrm{p}<.10$

Note. The segregation index is calculated as the absolute value of the difference between a school's percentage minority and that of the CBSA. The raw segregation index excludes the absolute value from the calculation, thereby indicating if a schools' percentage minority is lower or higher than the CBSA percentage minority. Both measures are weighted by school enrollment.

Source: Authors' calculations using private school data from the Private School Universe Survey, 2011-12 and public school data from the Common Core of Data's "Public Elementary/Secondary School Universe Survey", 2011-12; CBSA values from the 5-year American Community Survey estimates, 2008 through 2012.

We also use a second segregation measure to assess the private and public school context before the LSP was expanded. Frankenberg, Siegel-Hawley, and Wang (2010) suggest that schools where $90 \%$ or more of the population belongs to the same race/ethnicity are "hypersegregated". We use this suggested benchmark to create a homogeneity index, a binary measure scored one if $90 \%$ of a school's population belongs to the same race/ethnicity and zero otherwise. Table 3 examines the prevalence of school-level racial homogeneity across sectors at baseline. Private schools are significantly less likely to be racially homogeneous, as judged by this measure. Just $14 \%$ of private schools are identified as racially homogeneous, compared to $26 \%$ of public schools, a difference that is statistically significant $(\mathrm{p}<0.01)$. In addition, when we 
provide separate comparisons by CBSA classification, we see that private schools in metropolitan areas are, once again, significantly less likely to be identified as racially homogenous than public schools-14\% compared to $29 \%$. In micro areas, where there are far fewer schools, there is no difference between the two sectors in terms of the proportion of racially homogeneous schools.

Table 3.

Percentage of Schools that are Racially Homogeneous, by Sector and CBSA Type

\begin{tabular}{lccrccr}
\hline & \multicolumn{3}{c}{ Private Schools } & \multicolumn{2}{c}{ Public Schools } & \multicolumn{2}{c}{ Comparison } \\
\hline & $\mathrm{n}$ & $\begin{array}{c}\text { Percent } \\
\text { Racially } \\
\text { Homogeneous }\end{array}$ & $\mathrm{n}$ & $\begin{array}{c}\text { Percent } \\
\text { Racially } \\
\text { Homogeneous }\end{array}$ & Difference & $p$-value \\
\hline TOTAL & 332 & .14 & 1,278 & .26 & $-.12^{* * * *}$ & 0.00 \\
Metro Areas & 282 & .14 & 953 & .29 & $-.15^{* * *}$ & 0.00 \\
Micro Areas & 50 & .16 & 325 & .18 & .02 & 0.79 \\
\hline
\end{tabular}

Note. ${ }^{* * *}$ indicates significance at the $1 \%$ level

Source. Authors' calculations using private school data from the Private School Universe Survey, 2011-12 and public school data from the Common Core of Data's "Public Elementary/Secondary School Universe Survey", 2011-12; CBSA values from the 5-year American Community Survey estimates, 2008 through 2012.

Table 4 focuses on the school environments experienced by actual LSP scholarship users, broken out by student race. ${ }^{8}$ In particular, Table 4 presents enrollment-weighted average raw segregation indices for a student's former public school and new private school, with raw segregation indices calculated relative to the student's own race. For example, the average black LSP scholarship user left a school environment with a percentage black that was 34 percentage points higher than the CBSA percentage black to attend private schools that were only 9 percentage points higher than the CBSA percentage black. White students using LSP scholarships, on the other hand, tend to leave schools in which their own race is underrepresented to attend schools in which their race is over-represented. Finally, Hispanic students

\footnotetext{
${ }^{8}$ The sample in table 4 excludes students participating in the New Orleans-based LPS pilot program and charter school students.
} 
using an LSP scholarship tend to leave schools in which their race is slightly over-represented to attend schools in which their race is slightly under-represented.

Table 4.

School environments of transferring students

\begin{tabular}{lcccc}
\hline & \multicolumn{2}{c}{ Sending Public School } & \multicolumn{2}{c}{ Receiving Private School } \\
\cline { 2 - 5 } & $\mathrm{n}$ & $\begin{array}{c}\text { Own Race Distance } \\
\text { from CBSA }\end{array}$ & $\mathrm{n}$ & $\begin{array}{c}\text { Own Race Distance } \\
\text { from CBSA }\end{array}$ \\
\hline Black Transfers & 1395 & 34.12 & 1217 & 8.86 \\
White Transfers & 218 & -13.32 & 195 & 13.27 \\
Hispanic Transfers & 75 & 5.89 & 70 & -2.44 \\
\hline
\end{tabular}

Note. Table presents enrollment-weighted average raw segregation indices calculated as the difference between the school's percentage of the student's own race and the CBSA. Negative values indicate the average student faces a school environment in which their own race is under-represented. Positive values indicate over-representation.

The school-level descriptive statistics presented here reveal that both public and private schools in Louisiana are segregated. Students in private schools are significantly more likely to attend a school whose percentage of minority students is lower than that of the surrounding CBSA. Students in public schools, meanwhile, are more likely to be enrolled in schooling environments where $90 \%$ or more of a school's population belongs to the same race or ethnicity. Given that $80 \%$ of voucher users in the first year of the program were black, this suggests that the desegregating potential of the voucher program will be high, particularly if black LSP voucher users end up departing racially homogenous public schools for more diverse private schools.

\section{Research Design}

We turn now to an analysis of how the LSP changes racial segregation levels within Louisiana's schools. We start by defining a benchmark, which represents the racial composition goal a school could reasonably achieve given the racial demographics of that community. For our analysis, we allow the U.S. Census Bureau to set the benchmark, by using the racial composition of the 
CBSA. ${ }^{9}$ In total, the students in our sample attend schools in 25 different CBSAs. The schoolage population in these areas ranges from 26 percent to 78 percent white, with a mean value of 56 percent. The largest CBSA is the New Orleans-Metairie-Kenner metropolitan area (population, approximately 226,000) and the median population for a CBSA in our sample is 13,047 .

Having defined the CBSA as our community benchmark, we now answer our primary research question, "Have LSP transfers reduced or increased racial segregation in sending and receiving schools?" We code student transfers that move a school's racial composition closer to the racial composition of the relevant CBSA as segregation-reducing transfers, while transfers that move a school's racial composition further from this benchmark are coded as segregationincreasing transfers. Take, for example, a black student who leaves a public school in which black students are over-represented relative to the broader community. We would code this transfer as having a segregation-reducing effect on the student's former public school. On the other hand, if the school has a lower percentage of black students than the broader community, that transfer is coded as contributing to the increased racial segregation of the sending school. In cases where a black student leaves a school that is $100 \%$ black, this transfer is considered a null impact, as it is neither segregation-reducing nor segregation-increasing. The same logic applies to the analysis of the transfers of students who are white or Hispanic. If a student leaves or enters a school in which all of the students have that student's ethnicity, the effect of that transfer on integration must be zero. This measure takes an intuitive approach to studying the racial

\footnotetext{
${ }^{9}$ Core based statistical areas (CBSA) are defined by the U.S. Census Bureau; and are broken into two types. Metropolitan statistical areas represent geographical areas with populations of at least 50,000. Micropolitan statistical areas contain populations of between 10,000 and 50,000. By restricting our analysis to CBSAs, we exclude 62 students from our sample who live in rural counties that fall outside of metropolitan or micropolitan areas.
} 
segregation effects of a school choice policy and has been previously used by Greene, Mills, and Buck (2010), Jensen and Ritter (2009, 2010), and Ritter, Jensen, Kisida, and Bowen (2014). ${ }^{10}$

\section{Results}

Using student-level panel data, we document all LSP-related transfers and record the impact of the moves on school-level racial segregation. Figure 3 summarizes our primary analysis of the effects of LSP transfers on racial segregation in both sending and receiving schools. For sending schools, we identify transfers as "segregation-reducing" when a student of a given race leaves a school that is disproportionally composed of students of his same race relative to the greater CBSA. Conversely, outcomes that increase racial segregation occur when a student leaves a school in which the proportion of his race is less than the proportion of individuals of that race in the greater CBSA. As indicated in Figure 3, the overwhelming majority-82\% — of LSP student transfers reduced racial segregation in sending schools. Conversely, less than a fifth of transfers increased racial segregation in the former public schools of LSP students.

Racial segregation in receiving schools may be affected by student transfers too. We identify transfers that bring the school's racial proportions closer in line with those of the greater CBSA as reducing racial segregation and those transfers that bring the racial proportions further from those of the greater CBSA as increasing racial segregation. As Figure 3 shows, LSP transfers result in slightly more negative outcomes for receiving schools: 803 student transfers

\footnotetext{
${ }^{10}$ The empirical approach employed in this study may be critiqued for not taking into consideration the magnitude of any changes in the traditional public school environment after a voucher student transfers. If a small number of over-represented students transfer from a traditional public school, we code the effects of the voucher program as "improving integration", even though the impact of this small number of transfers on the school environment may be quite small. We acknowledge this criticism but also stress that the purpose of this evaluation is to assess the segregating effects of a program that was not explicitly designed as a desegregation tool. Indeed, if participation in the LSP was the only desegregation effort made by a school district, it is not clear that this would achieve the goal of desegregation.
} 


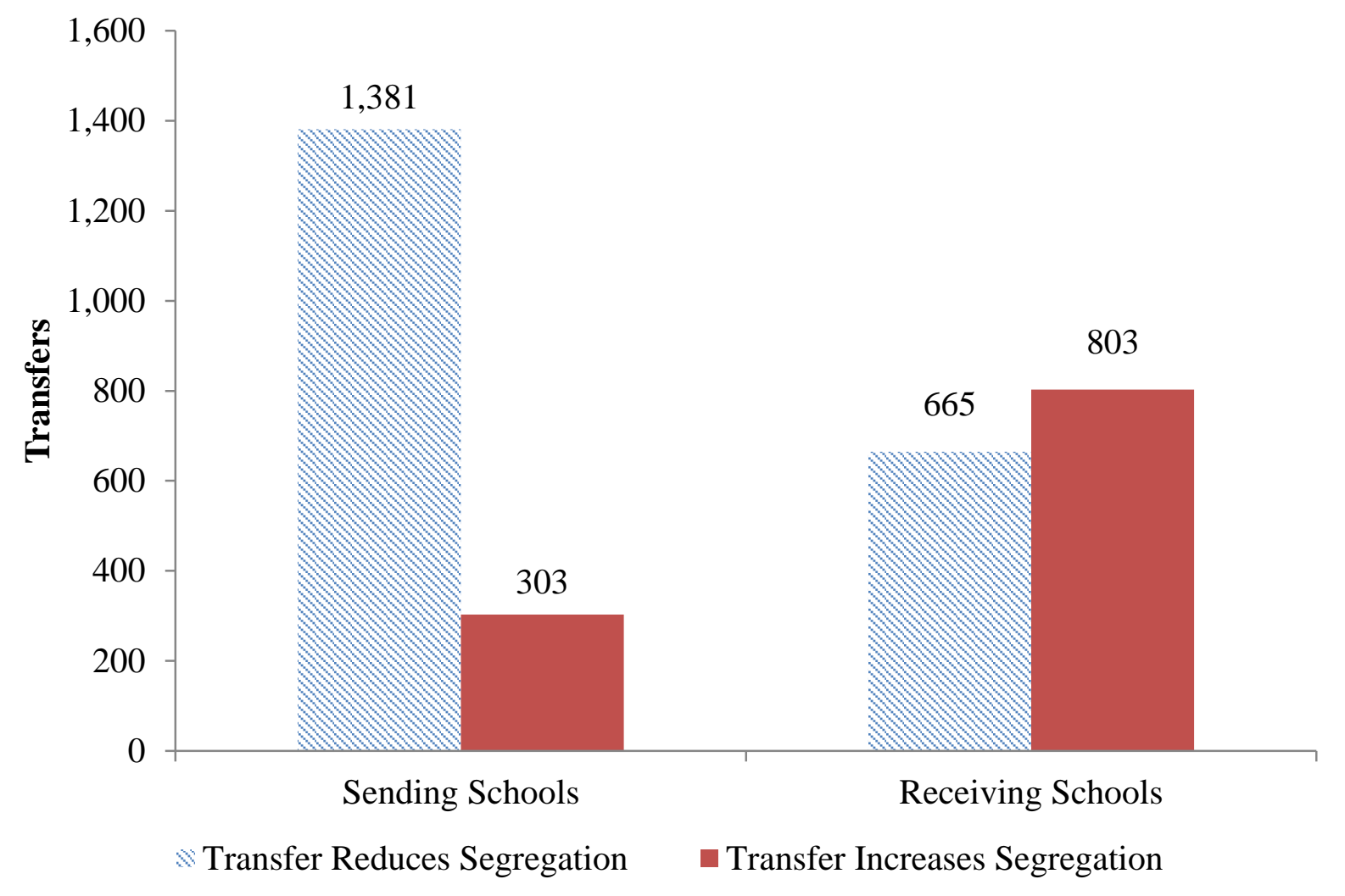

Figure 3. Impacts of Voucher Transfers on Racial Segregation. Sending schools are traditional public schools - this category -excludes private New Orleans schools that were already participating in the voucher program and charter schools. Impacts on receiving schools are based on student transfers from traditional public schools only. Transfers from sending schools come close $(1,684)$ but do not completely sum to the size of the full analysis sample $(1,741)$ because this figure only examines transfers for the three largest racial categories. The numbers of transfers from sending and into receiving schools don't match because a small number of private schools do not appear in the Private School Universe Study, which is a voluntary NCES survey. Number of transfers excluded because sending school was 100\% same race $=4$ (black), 0 (Hispanic), and 0 (white). Number of transfers excluded because receiving school was $100 \%$ same race $=32$ (black), 0 (Hispanic), and 7 (white). Chi-square tests for goodness-of-fit indicate the observed differences are significant for sending schools $(p<0.01)$ and significant for receiving schools $(p=.0003)$.

Source. Authors' calculations.

statistically significant. Thus, while our analysis indicates large positive impacts of the LSP vouchers on integration for traditional public schools, the effect on private receiving schools is small and negative. Because the program's positive effect on increasing integration in affected public schools is so much larger than its negative effect on decreasing integration in affected 
private schools, the total net effect of the Louisiana Scholarship Program on racial integration in schools is positive.

In Table 5, we examine transfer impacts for three major student subgroups — white, black, and Hispanic. Given that $80 \%$ of voucher users are black, it is unsurprising that the majority of student transfers are for black students. Within this group, 92\% of transfers reduce segregation at the sending school, compared to $24 \%$ of white student transfers and $56 \%$ of Hispanic student transfers. In receiving schools, $45 \%$ of black student transfers reduce segregation, compared to $28 \%$ for white students and $96 \%$ for Hispanic students.

Table 5 .

Impact on Racial Segregation in Sending and Receiving Schools across the state of Louisiana

\begin{tabular}{|c|c|c|c|c|}
\hline \multirow[b]{2}{*}{ Type of Transfer } & \multicolumn{2}{|c|}{ Sending } & \multicolumn{2}{|c|}{ Receiving } \\
\hline & $\mathrm{N}$ & $\%$ & $\mathrm{~N}$ & $\%$ \\
\hline \multicolumn{5}{|l|}{ Black Students } \\
\hline Reduce Segregation & 1,286 & 92 & 542 & 45 \\
\hline Increase Segregation & 105 & 8 & 659 & 55 \\
\hline \multicolumn{5}{|l|}{ White Students } \\
\hline Reduce Segregation & 53 & 24 & 56 & 28 \\
\hline Increase Segregation & 165 & 76 & 141 & 72 \\
\hline \multicolumn{5}{|l|}{ Hispanic Students } \\
\hline Reduce Segregation & 42 & 56 & 67 & 96 \\
\hline Increase Segregation & 33 & 44 & 3 & 4 \\
\hline $\begin{array}{l}\text { Percent of overall transfers that } \\
\text { reduce racial segregation }\end{array}$ & & $82 \%$ & & $45 \%$ \\
\hline
\end{tabular}

Note. Sending schools are traditional public schools - this category excludes private New Orleans schools that were already participating in the voucher program and charter schools. Impacts on receiving schools are based on student transfers from traditional public schools only. Transfers from sending schools do not sum to the size of the full analysis sample $(1,741)$ because this table only examines transfers for the three largest racial categories. The numbers of transfers from sending and into receiving schools do not match because a small number of private schools don't appear in the Private School Universe Study, which is a voluntary NCES survey. Number of transfers excluded because sending school was 100\% same race $=4$ (black), 0 (Hispanic), and 0 (white). Number of transfers excluded because receiving school was $100 \%$ same race $=32$ (black), 0 (Hispanic), and 7 (white). Chi-square tests for goodness-of-fit indicate the observed differences are significant for sending schools $(p<0.01)$ and significant for receiving schools $(p=.0003)$.

Source. Authors' calculations. 


\section{Analysis of Effects within the Desegregation Districts}

While the prior analysis focused on LSP transfers in general, it is also relevant to examine how these transfers are differentially impacting public schools in districts under federal desegregation orders. We examine this question by restricting the primary analysis to LSP schools in the 34 public school districts that are currently under desegregation orders. ${ }^{11}$ When we restrict our analysis to this subgroup, we find that, once again, transfers significantly reduce segregation in sending schools and have null impacts on receiving schools. As Figure 4 shows, 354 LSP transfers (75\% of all transfers) reduce segregation in the sending schools. In receiving schools meanwhile, there is no statistically significant difference between the number of segregationreducing and segregation-increasing transfers.

Table 6 breaks out these results by race. The same general patterns hold as before. For black students, $87 \%$ of transfers reduce segregation at the sending school, compared to $33 \%$ of white student transfers and $38 \%$ of Hispanic student transfers. In receiving schools, $57 \%$ of black student transfers reduce segregation, compared to just $4 \%$ for white students and $100 \%$ for Hispanic students.

These patterns of findings generally hold when we further narrow our analysis to just the 24 districts in which the U.S. is listed as a party in the original desegregation cases. Specifically, LSP transfers in this subsample reduce racial segregation in sending schools $80 \%$ of the time ( $p$ $<.01)$ and increase racial segregation in receiving schools $66 \%$ of the time $(p=.02)$.

\footnotetext{
11 See Table A1 in the appendix for the list of school districts under federal desegregation orders
} 


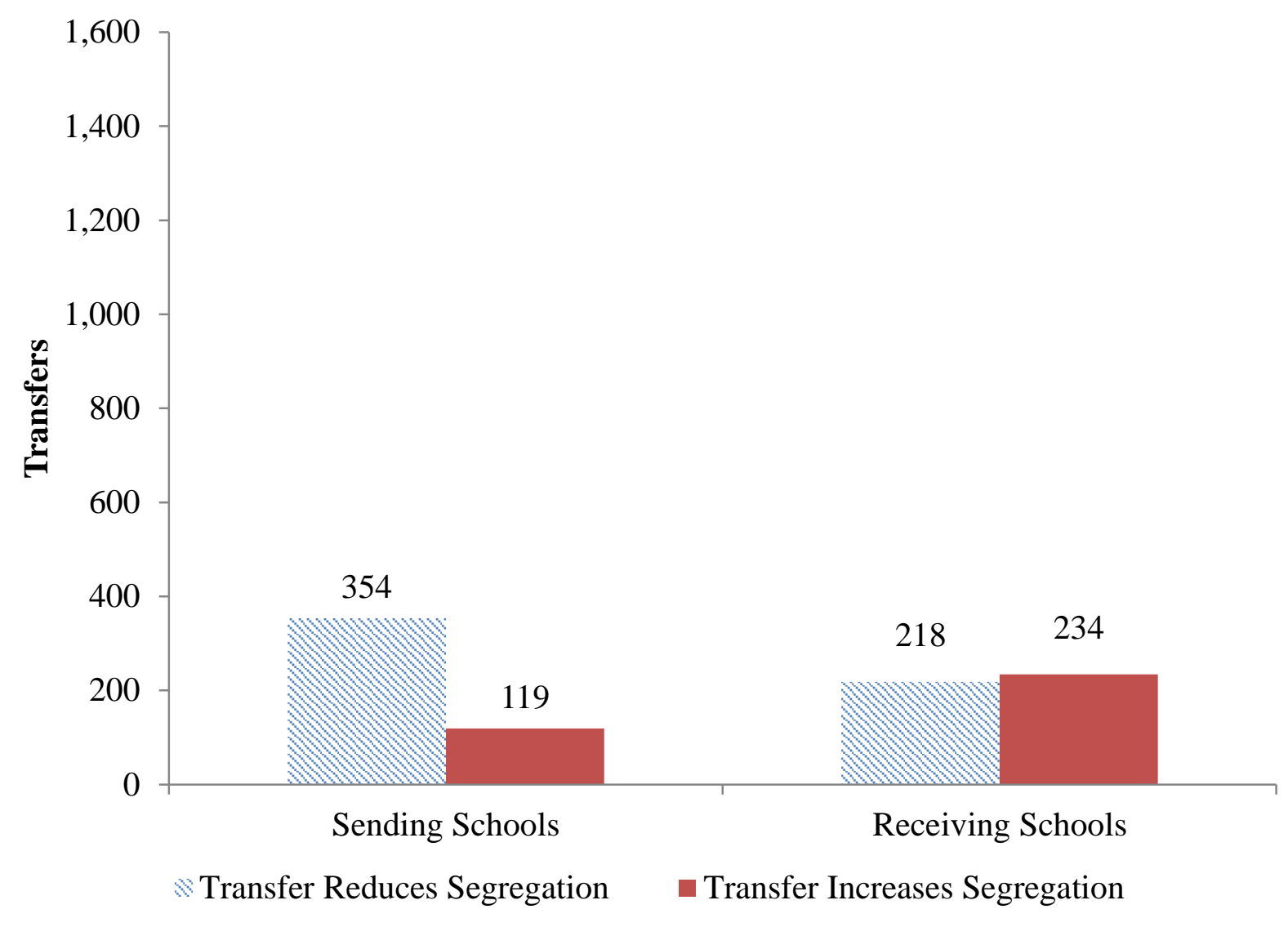

Figure 4. Impacts of Voucher Transfers on Racial Segregation in Districts under Desegregation Orders. Sending schools are traditional public schools under federal desegregation orders. Impacts on receiving schools are based on student transfers from traditional public schools under federal desegregation orders. Number of transfers excluded because sending school was $100 \%$ same race $=0$ (black), 0 (Hispanic), and 0 (white). Number of transfers excluded because receiving school was $100 \%$ same race $=0$ (black), 0 (Hispanic), and 0 (white). Chi-square tests for goodness-of-fit indicate the observed differences are significant for sending schools $(\mathrm{p}<0.01)$ and insignificant for receiving schools $(\mathrm{p}=.4517)$.

Source. Authors' calculations. 
Table 6.

Impact on Racial Segregation in Schools under Federal Desegregation Orders

\begin{tabular}{|c|c|c|c|c|}
\hline \multirow[b]{2}{*}{ Type of Transfer } & \multicolumn{2}{|c|}{ Sending } & \multicolumn{2}{|c|}{ Receiving } \\
\hline & $\mathrm{N}$ & $\%$ & $\mathrm{~N}$ & $\%$ \\
\hline \multicolumn{5}{|l|}{ Black Students } \\
\hline Reduce Segregation & 318 & 87 & 204 & 57 \\
\hline Increase Segregation & 49 & 13 & 154 & 43 \\
\hline \multicolumn{5}{|l|}{ White Students } \\
\hline Reduce Segregation & 31 & 33 & 3 & 4 \\
\hline Increase Segregation & 62 & 67 & 80 & 96 \\
\hline \multicolumn{5}{|l|}{ Hispanic Students } \\
\hline Reduce Segregation & 5 & 38 & 11 & 100 \\
\hline Increase Segregation & 8 & 62 & 0 & 0 \\
\hline $\begin{array}{l}\text { Percent of overall transfers that } \\
\text { reduce racial segregation }\end{array}$ & & $75 \%$ & & $48 \%$ \\
\hline
\end{tabular}

Note. Sending schools are traditional public schools under federal desegregation orders only. Impacts on receiving schools are based on student transfers from traditional public schools under federal desegregation orders. Number of transfers excluded because sending school is $100 \%$ same-race is zero. Number of transfers excluded because receiving school is $100 \%$ same-race is zero. Chi-square tests for goodness-of-fit indicate the observed differences are significant for sending schools $(p<0.01)$ and insignificant for receiving schools $(p=.4517)$.

Source. Authors' calculations.

The results presented here reveal large positive impacts of the LSP vouchers for traditional public schools, which have long been the focus of federal efforts to desegregate. These positive findings hold when we restrict the sample to include only the districts under active federal desegregation orders and again when we further restrict the sample to districts where the U.S. is a party to the suit. Although the effect on private receiving schools is consistently small, it is negative and statistically significant in the overall sample but not significant in the samples limited to areas under desegregation orders.

\section{Sensitivity Test: Choosing Between Two Potential Panel Measures of Racial Segregation}

The racial segregation measure used in this analysis uses panel data to assess the impacts of the LSP on racial segregation, judging the direction of impacts by comparing against a racial 
composition benchmark. As described above, Zimmer et al. (2009) also employ a panel approach to assess the impacts of a school choice program on racial segregation levels but compare the racial composition of the receiving school to that of the sending school instead of an external benchmark. When a student leaves a public school in which his race is over-represented for a private school in which his race is also over-represented but to a greater degree, the Zimmer et al. (2009) panel approach could be regarded as superior to the panel approach used here. Our panel approach that uses a benchmark would rate such a move as reducing racial segregation for the sending school and increasing racial segregation for the receiving school. A transfer measure without a racial composition benchmark (e.g., Zimmer et al. 2009), however, would assign a single rating to that move- - judging it as increasing racial segregation, which is perhaps more intuitive to many people.

Because readers may disagree over which approach is superior and to ensure transparency regarding our choice of measure, we provide Table A3 in the appendix; which breaks apart all potential scenarios in which a student transfer is rated as "segregation-reducing" in the sending school. The problematic example is Scenario 6, when the student departs a sending school in which his race is over-represented (thus, being rated as segregation-reducing by our panel measure) and arrives in a private school in which his race is even more overrepresented (thus, being rated as segregation-increasing by our panel measure). This scenario captures only $16 \%$ of all transfers, thus reducing any concerns that the choice of measure is driving our results.

\section{Limitations}

There are at least three limitations that restrict the generalizability of the methods and findings presented here. First, the measure employed in this paper to calculate the racial segregation 
impacts of the voucher on sending schools usually includes all students who depart a public school. Technically, it would be possible for this sample to include students who drop out of school or move out of the state entirely. We avoid such an error in this study by limiting the sample to those students who actually used an LSP voucher and, thus, arrived in a participating private school in the fall of 2012. Researchers seeking to imitate our methods should beware of this limitation of the integration measure used here and restrict their sample appropriately.

Second, integration is measured in this paper using a measure that rates transfers in a binary fashion — as either segregation-reducing or segregation-increasing. The benefit of this approach is that it is easy to understand and interpret but it could be criticized for equally weighting a transfer from a school in which the student's race is only slightly under-represented and a transfer from a school in which the student's race is dramatically under-represented. It is possible that a more sophisticated measure could be employed that would weight transfers and express the overall segregation impact on a continuous scale, although it is not clear how one would interpret the numbers produced by such a measure.

Finally, our analysis of the effect of school choice on racial segregation in schools draws upon a single private school voucher program in a particular state. Thus our study has limited external validity. The LSP is heavily targeted to low-income students in perennially underperforming schools, which at least partially explains the fact that most of the program participants are black students in public schools that are overwhelmingly black in their composition. The LSP appears to have been designed in ways that all but assure that its effect on traditional public schools will be to better integrate them racially. Not every school choice program is designed that way. Second, Louisiana is a distinctive U.S. state in its demographics, 
history, and culture. It is possible that even a program designed exactly like the LSP might have different integration effects in a state unlike Louisiana, such as Utah or Rhode Island.

\section{Conclusion}

This article presents an analysis of the impacts of the Louisiana Scholarship Program (LSP) on racial segregation in Louisiana public and private schools. Overall, we find large, positive reductions in racial segregation in public schools that are consistent across our samples and small increases in racial segregation in private schools that are not consistent across our samples as a result of this school voucher program

Our primary analysis uses student-level panel data to track individual student transfers as they switch from the public to the private sector. Outcomes that reduce racial segregation occur when a student of a given race leaves a school in which his race is over-represented relative to the greater CBSA. Conversely, outcomes that increase racial segregation occur when a student leaves a school in which his race is under-represented relative to the CBSA. In keeping with Jeynes' (2000) prediction that school choice would benefit minorities and the poor the most, this analysis reveals that the vouchers used by the low-income, mostly minority recipients have positively impacted public school desegregation efforts. By leaving schools in which they were racially overrepresented, $82 \%$ of voucher users reduced racial segregation in Louisiana public schools, bringing those public school racial populations closer in line with those of the broader communities. Positive impacts are particularly sizeable for black students, who constitute the majority of voucher recipients. Ninety-two percent of LSP transfers for black students result in a reduction in racial segregation for sending schools in the transfer sample. Student transfers have a small, negative impact on the schools they transfer to by increasing racial segregation. Just 
$45 \%$ of all transfers reduced racial segregation in the receiving schools. Combining the two findings, the overall net effect of the LSP on school-level racial integration is positive.

An analysis of the subgroup of students leaving districts under active federal desegregation orders demonstrates that transfers significantly reduce racial segregation in these 34 public school districts, the very districts that have been the subject of the greatest segregation concerns. In total, $75 \%$ of transfers reduce racial segregation in the sending schools in this subgroup. The impact on receiving schools in this subgroup is statistically equivalent to zero. While acknowledging that LSP transfers have resulted in a small, negative impact on private school racial segregation, the results of this study allow us to confidently conclude that the LSP has not harmed desegregation efforts in Louisiana public schools. To the contrary, public schools in Louisiana, including those public schools under active desegregation orders, are significantly less racially stratified as a direct result of the statewide school voucher program. 


\section{References}

Altonji, J.G., Huang, C.I., \& Taber, C.R. (2015). Estimating the cream skimming effect of school choice. Journal of Political Economy, 123(2): 266-324.

Berliner, D., Farrell, W., Huerta, L., and Mickelson, R. (2000). Will vouchers work for lowincome students? (Report No. CERAI-00-31) Milwaukee, WI: Center for Education Research, Analysis, and Innovations. Retrieved from http://nepc.colorado.edu/files/cerai$\underline{00-37 . h t m}$

Bifulco, R., \& Ladd, H. F. (2006). School choice, racial segregation, and test-score gaps: Evidence from North Carolina's charter school program. Journal of Policy Analysis and Management, 36(1), 31-56.

Brumfield v. Dodd, 405 F. Supp. 338, 342 (E.D. La. 1975)

Brumfield v. Louisiana Bd. of Edu., No.14-31010 F.3d (5th Cir. 2015)

Burgess, S., Wilson, D., \& Lupton, R. (2005). Parallel lives? Ethnic segregation in schools and neighborhoods. Urban Studies, 42(7), 1027-1056.

Clotfelter, C. T. (1999). Public school segregation in metropolitan areas. Land Economics, 75(4): 487-504.

DeVore, D. E., \& Logsdon, J. (1991). Crescent City schools: Public education in New Orleans, 1841-1991. Lafayette, LA: The Center for Louisiana Studies, University of Southwestern Louisiana.

Cobb, C. D. and Glass, G.V. (1999). Ethnic segregation in Arizona charter schools. Education Policy Analysis Archives, 7 (1). Retrieved from epaa.asu.edu/ojs/article/download/536/65

Forster, G. (2006a). Segregation levels in Cleveland Public Schools and the Cleveland Voucher Program. Indianapolis, IN: The Milton and Rose D. Friedman Foundation and the Buckeye Institute. Retrieved from http://www.scohio.org/PDF/Segregation_Cleveland.pdf

Forster, G. (2006b). Segregation levels in Milwaukee Public Schools and the Milwaukee Voucher Program. Indianapolis, IN: The Milton and Rose D. Friedman Foundation. Retrieved from http://www.edchoice.org/CMSModules/EdChoice/FileLibrary/86/Segregation\%20Levels \%20in\%20Milwaukee\%20Public\%20Schools\%20and\%20the\%20Milwaukee\%20Voucher \%20Program.pdf

Frankenberg, E., \& Lee, C. (2002). Race in American public schools: Rapidly Resegregating School Districts. Cambridge, MA: The Civil Rights Project, Harvard University. Retrieved from http://civilrightsproject.ucla.edu/research/k-12-education/integration-anddiversity/race-in-american-public-schools-rapidly-resegregating-school-districts 
Frankenberg, E., Siegel-Hawley, G., and Wang, J. (2010). Choice without Equity: Charter School Segregation and the Need for Civil Rights Standards. Los Angeles, CA: The Civil Rights Project, University of California Los Angeles. Retrieved from http://civilrightsproject.ucla.edu/research/k-12-education/integration-and-diversity/choicewithout-equity-2009-report/frankenberg-choices-without-equity-2010.pdf

Friedman, M. (1955). The role of government in education. In R. A. Solo (Ed.), Economics and the Public Interest (pp. 123-144). New Brunswick, NJ: Rutgers University Press.

Galston, W. (2004). Civic republicanism, political pluralism, and the regulation of private schools. In P. J. Wolf \& S. Macedo (Eds.), Educating citizens: International perspectives on civic values and school choice. Washington, DC: Brookings Institution Press.

Garcia, D. R. (2008). Academic and racial segregation in charter schools: Do parents sort students into specialized charter schools? Education and Urban Society, 40(5), 590-612.

Glenn, C. L. (2000). The ambiguous embrace. Princeton, NJ: Princeton University Press.

Glenn, C. L. (2011). Contrasting models of state and school. New York: Continuum.

Greene, J. P. (2005). Choosing integration. In J. Scott T. (Ed.), School choice and diversity: What the evidence says (pp. 27-41). New York: Teachers College Press.

Greene, J. P. (2011). Why America needs school choice. New York City, NY: Encounter Books.

Greene, J. P., Mills, J. N., \& Buck, S. (2010). The Milwaukee Parental Choice Program's effect on school integration (No. 20). Fayetteville, AR: School Choice Demonstration Project, University of Arkansas. Retrieved from http://www.uark.edu/ua/der/SCDP/Milwaukee_Eval/Report_20.pdf.

Greene, J. P., \& Winters, M. A. (2007). An evaluation of the effect of DC's voucher program on public school achievement and racial integration after one year. Catholic Education: A Journal of Inquiry and Practice, 11(1), 83-101.

Gutmann, A. (2002). Assessing arguments for school choice: Pluralism, parental rights, or educational results? In A. Wolfe (Ed.), School Choice: The Moral Debate (pp. 126-148), Princeton, NJ: Princeton University Press.

Henig, J. (1994). The call for choice and radical reform. In Henig, J. (Ed.), Rethinking school choice: Limits of the market metaphor. Princeton, NJ: Princeton University Press.

Henig, J. R. (1996). The local dynamics of choice: Ethnic preferences and institutional responses. In B. Fuller \& R. Elmore F. (Eds.), Who chooses? Who loses? Culture, institutions, and the unequal effect of school choice. New York: Teachers College Press.

Jensen, N. C., \& Ritter, G. W. (2009). An analysis of the impact of charter schools on desegregation efforts in Little Rock, Arkansas (Arkansas Education Report No. 6-3). Fayetteville, AR: Office for Education Policy, University of Arkansas. 
Jensen, N. C., \& Ritter, G. W. (2010). Updated analysis of racial segregation in Pulaski County charter and traditional public schools (Arkansas Education Report No. 7-1). Fayetteville, AR: Office for Education Policy, University of Arkansas. Retrieved from http://www.uark.edu/ua/oep/AER/7_1_Updated_Analysis_of_Racial_Segregation_in_Pul aski_County_Charter_and_Traditional_Public_Schools.pdf

Jeynes, W. (2000). Assessing school choice: A balanced perspective. Cambridge Journal of Education, 30 (2), 223-241.

Jeynes, W. (2014a). School choice: A balanced approach. Santa Barbara, CA: Praeger.

Jeynes, W. (2014b). School choice and the achievement gap. Education \& Urban Society, 46 (2), 163-180.

Lacireno-Paquet, N., Holyoke, T. T., Moser, M., \& Henig, J., R. (2002). Creaming versus cropping: Charter school enrollment practices in response to market incentives. Educational Evaluation and Policy Analysis, 24(2), 145-158.

Ladson-Billings, G. (2004). Landing on the wrong note: The price we paid for Brown. Educational Researcher, 33(7), 3-13.

Landphair, J. (1999). Sewerage, sidewalks, and schools: The New Orleans Ninth Ward and public school desegregation, Louisiana History: The Journal of the Louisiana Historical Association, 40(1): 35-62.

Macedo, S., \& Wolf, P. J. (2004). Introduction: School choice, civic values, and the problem of policy comparison. In P. J. Wolf \& S. Macedo (Eds.), Educating citizens: International perspectives on civic values and school choice. Washington, DC: Brookings Institution Press.

Peterson, P. E. (2006). Choice and competition in American education. Lanham, MD: Rowan \& Littlefield.

Ritter, G. W., Jensen, N. C., Kisida, B., \& Bowen, D. H. (2014). Urban school choice and integration: The effect of charter schools in Little Rock. Forthcoming in Education and Urban Society.

Willms, D. J., \& Echols, F. H. (1993). The Scottish experience of parental school choice. In School choice: Examining the evidence (pp. 49-68).

Zimmer, R., Gill, B., Booker, K., Lavertu, S., Sass, T., \& Witte, J. (2009). Charter schools in eight states: Effects on achievement, attainment, integration, and competition. Santa Monica, CA: RAND. 


\section{Appendices}

Table A1.

Public school districts under Federal Desegregation Orders

\begin{tabular}{|c|c|}
\hline District Name & $\begin{array}{l}\text { U.S. is a Party to the } \\
\text { Desegregation Order }\end{array}$ \\
\hline Avoyelles Parish & YES \\
\hline Bienville Parish & YES \\
\hline Bossier Parish & YES \\
\hline Caddo Parish & YES \\
\hline Catahoula Parish & YES \\
\hline Claiborne Parish & YES \\
\hline Concordia Parish & YES \\
\hline Desoto Parish & YES \\
\hline Franklin Parish & YES \\
\hline Jackson Parish & YES \\
\hline Lasalle Parish & YES \\
\hline Lincoln Parish & YES \\
\hline City Of Monroe School District & YES \\
\hline Plaquemines Parish & YES \\
\hline Pointe Coupee Parish & YES \\
\hline Richland Parish & YES \\
\hline Sabine Parish & YES \\
\hline St. Helena Parish & YES \\
\hline St. James Parish & YES \\
\hline St. John The Baptist Parish & YES \\
\hline St. Martin Parish & YES \\
\hline St. Mary Parish & YES \\
\hline St. Tammany Parish & YES \\
\hline West Carroll Parish & YES \\
\hline Acadia Parish & $\mathrm{NO}$ \\
\hline Allen Parish & NO \\
\hline Assumption Parish & $\mathrm{NO}$ \\
\hline Iberia Parish & $\mathrm{NO}$ \\
\hline Jefferson Davis Parish & $\mathrm{NO}$ \\
\hline Lafourche Parish & $\mathrm{NO}$ \\
\hline Madison Parish & $\mathrm{NO}$ \\
\hline Ouachita Parish & $\mathrm{NO}$ \\
\hline Tangipahoa Parish & $\mathrm{NO}$ \\
\hline Winn Parish & $\mathrm{NO}$ \\
\hline
\end{tabular}

Source: United States' Memorandum in Support of its Motion for Further Relief, Brumfield v.

Dodd, Civ. A. No. 71-1316, (p.4) 
Table A2.

Results based on sample excluding students formerly attending charter, magnet, and OPSB schools

\begin{tabular}{|c|c|c|c|c|}
\hline \multirow[b]{2}{*}{ Type of Transfer } & \multicolumn{2}{|c|}{ Sending } & \multicolumn{2}{|c|}{ Receiving } \\
\hline & $\mathbf{N}$ & $\%$ & $\mathbf{N}$ & $\%$ \\
\hline \multicolumn{5}{|l|}{ All students } \\
\hline Good Outcome & 1264 & 0.82 & 582 & 0.43 \\
\hline Bad Outcome & 281 & 0.18 & 769 & 0.57 \\
\hline Difference & $983^{*}$ & $0.64 *$ & $-187 *$ & $-0.14 *$ \\
\hline \multicolumn{5}{|l|}{ White Students } \\
\hline Good Outcome & 53 & 0.26 & 49 & 0.27 \\
\hline Bad Outcome & 148 & 0.74 & 131 & 0.73 \\
\hline Difference & $-95^{*}$ & -0.47 & $-82^{*}$ & $-0.46^{*}$ \\
\hline \multicolumn{5}{|l|}{ Black Students } \\
\hline Good Outcome & 1173 & 0.92 & 469 & 0.42 \\
\hline Bad Outcome & 101 & 0.08 & 635 & 0.58 \\
\hline Difference & $1072 *$ & $0.84^{*}$ & $-166^{*}$ & $-0.15^{*}$ \\
\hline \multicolumn{5}{|l|}{ Hispanic Students } \\
\hline Good Outcome & 38 & 0.54 & 64 & 0.96 \\
\hline Bad Outcome & 32 & 0.46 & 3 & 0.04 \\
\hline Difference & 6 & 0.09 & $61 *$ & $0.91 *$ \\
\hline Total transfers & 1,545 & & 1,351 & \\
\hline $\begin{array}{l}\text { Proportion of overall } \\
\text { transfers that are } \\
\text { good }\end{array}$ & 0.82 & & 0.43 & \\
\hline
\end{tabular}

$*-\mathrm{p}<.05$

Note: Sending schools are traditional public schools - this category excludes private New Orleans schools that were already participating in the voucher program, public charter schools, public magnet schools, and open-enrollment Orleans Parish School Board (OPSB) schools. Impacts on receiving schools are based on student transfers from traditional public schools only. Chi-square tests for goodness-of-fit indicate the observed differences are significant for sending schools $(p<0.01)$ and significant for receiving schools $(p<0.01)$. 
Table A3.

Comparing Methodologies: Transfer Measures of Integration, With and Without a Racial Benchmark

\begin{tabular}{|c|c|c|c|c|}
\hline & \multicolumn{3}{|c|}{$\begin{array}{c}\text { Our Approach: } \\
\text { Using a Benchmark }\end{array}$} & $\begin{array}{c}\text { Zimmer et al. (2009) } \\
\text { Approach: } \\
\text { No Benchmark }\end{array}$ \\
\hline & \multicolumn{3}{|c|}{ Impact on Sending School } & Net Impact \\
\hline & $\begin{array}{c}\text { Transfer } \\
\text { Rating }\end{array}$ & Count & Proportion & Transfer Rating \\
\hline 1. $\mathrm{R}^{*}>\mathrm{R}_{0}>\mathrm{R}_{1}$ & $\mathrm{Bad}$ & 74 & .05 & Good \\
\hline 2. $\mathrm{R}_{0}>\mathrm{R}^{*}>\mathrm{R}_{1}$ & Good & 536 & .34 & Good \\
\hline 3. $\mathrm{R}_{0}>\mathrm{R}_{1}>\mathrm{R}^{*}$ & Good & 504 & .32 & Good \\
\hline 4. $\mathrm{R}^{*}>\mathrm{R}_{1}>\mathrm{R}_{0}$ & $\mathrm{Bad}$ & 70 & .04 & $\mathrm{Bad}$ \\
\hline 5. $\mathrm{R}_{1}>\mathrm{R}^{*}>\mathrm{R}_{0}$ & $\mathrm{Bad}$ & 141 & .09 & $\mathrm{Bad}$ \\
\hline 6. $\quad \mathrm{R}_{1}>\mathrm{R}_{0}>\mathrm{R}^{*}$ & Good & 255 & .16 & $\mathrm{Bad}$ \\
\hline TOTAL & & 1,580 & 1.00 & \\
\hline
\end{tabular}

Note: $\mathrm{R}_{0}$ denotes percent of race $\mathrm{R}$ in sending school; $\mathrm{R}_{1}$ denotes percent of race $\mathrm{R}$ in receiving school; $\mathrm{R}^{*}$ denotes benchmark. Only the subset of students who were present in the analyses of impacts on both sending and receiving schools are included. Scenario 6 represents the problematic situation in which a student leaves a public school in which his race is overrepresented for a private school in which his race is also over-represented. 


\begin{abstract}
About the Authors
Anna J. Egalite is an Assistant Professor in the Department of Educational Leadership, Policy, and Human Development in the College of Education at North Carolina State University. She holds a Ph.D. in education policy from the University of Arkansas and an M.Ed. from the University of Notre Dame's Alliance for Catholic Education. She completed a postdoctoral fellowship in the Program on Education Policy and Governance at Harvard University. Her research focuses on the evaluation of education policies and programs intended to close racial and economic achievement gaps, such as the introduction of market forces into education through school choice and competition.
\end{abstract}

Jonathan N. Mills is a Postdoctoral Fellow at the Education Research Alliance for New Orleans at Tulane University. His research focuses on the effects of school choice programs on student achievement and non-academic outcomes, as well as the benefits and unintended consequences of college financial aid programs. Mills received his $\mathrm{Ph}$. D. in education policy from the University of Arkansas in 2015. He additionally holds a Bachelor of Science and a Master of Arts in economics from the University of Missouri.

Patrick J. Wolf is Distinguished Professor of Education Policy and $21^{\text {st }}$ Century Endowed Chair in School Choice at the University of Arkansas in Fayetteville. He has authored, co-authored, or co-edited four books and over 100 journal articles, book chapters, and policy reports on school choice, civic values, public management, special education, and campaign finance. He received his Ph.D. in Political Science from Harvard University in 1995.

\begin{abstract}
About the SCDP
Housed within the Department of Education Reform at the University of Arkansas, the School Choice Demonstration Project (SCDP) is an education research center dedicated to the nonpartisan study of the effects of school choice policy. Led by Dr. Patrick J. Wolf, the SCDP's national team of researchers, institutional research partners and staff are devoted to the rigorous evaluation of school choice programs and other school improvement efforts across the country. The SCDP is committed to raising and advancing the public's understanding of the strengths and limitations of school choice policies and programs by conducting comprehensive research on what happens to students, families, schools and communities when more parents are allowed to choose their child's school. Reports from past SCDP studies are available at http://www.uaedreform.org/school-choice-demonstration-project/.
\end{abstract}

\title{
About ERA-NOLA
}

The Education Research Alliance for New Orleans is based within the School of Liberal Arts at Tulane University. The objective of ERA-New Orleans is to provide objective, rigorous, and useful research to improve schools in New Orleans and beyond. For more information about ERA-New Orleans, including some of the studies mentioned in this brief, please visit www.educationresearchalliancenola.com. 